\title{
THE ANALYSIS OF PUBLIC RELATIONS ROLE IN IMPROVING CORPORATE SOCIAL RESPONSIBILITY
}

\author{
UDC: 659.4:005.35 \\ Preliminary Communication \\ Ružica ĐERVIDA-LEKANIĆ ${ }^{1}$, Cariša BEŠI $\check{C}^{2}$, \\ Doloris BEŠIĆ-VUKAŠINOVIĆ ${ }^{3}$, Snežana BEŠIĆ ${ }^{4}$ \\ ${ }^{1}$ Independant University Banja Luka, 78000 Banja Luka, Veljka Mlađenovića 12e, Bosnia and Herzegovina \\ ${ }^{2}$ University of Kragujevac, Faculty of Technical Sciences in Čačak, 32000 Čačak, Svetog Save 65, \\ Republic of Serbia \\ E-mail: carisa.besic@sbb.rs \\ ${ }^{3}$ University of UNION - "Nikola Tesla", Faculty of Business Studies and Law, 11000 Beograd, \\ Staro sajmište 29, Republic of Serbia \\ ${ }^{4}$ Higher Education Railway School of Professional Studies, 11000 Beograd, Zdravka Čelara 14, \\ Republic of Serbia
}

Paper received: 08.02.2016.; Paper accepted: 25.03.2016.

The main objective of modern business is achievement of business excellence and world-class of products and services. Companies which actively and continuously apply modern management methods and techniques, especially in marketing, have significantly better chance to strengthen their competitive capability on global market and to assume stable market position with perspective for further market development. Modern business philosophy implies that organization has to be responsible for its actions and steps towards all stakeholders in the environment. Attaining of business excellence goals of an organization presupposes built corporate social responsibility. The research results presented in this paper were used to analyze the possibilities of using modern methods and techniques of public relations in business organizations and improve corporate social responsibility on the market of Bosnia and Herzegovina.

Keywords: Corporate social responsibility, Public relations, Organization, Quality, Bosnia and Herzegovina.

\section{INTRODUCTION}

Achieving competitive ability in terms of the global market is a very complex process which requires the coordination of all business functions in the company as well as an investment of exceptional financial and marketing efforts. Competitive ability is difficult to gain but easy to lose in the offensive environment of global competition, (Đorđević et al., 2012). Regarding the specific aspects which affect performance in international frameworks, we can particularly stand out:

- Productivity,

- Quality and

- Innovations, (Bešić \& Đorđević, 2014).
The struggle for competitive advantage is the struggle for business productivity. The success of the company is associated with the established concept of quality, enabling achievement of competitive advantage based on improving business productivity. Quality becomes the primary development objective, which is realized through the achievement of operational excellence and reaching world-class products and services, while the holders of quality improvement operations are employed in the organization. Employees are those who create quality in the organization, by improving the productivity of their knowledge and work.

From the traditional understanding of the organization, where all business functions have equal importance, companies must turn to 
proactive thinking, which involves understanding and creating changes, as well as giving importance to those business functions that enable the company to create, maintain and improve the competitive position in the global market. Functions that have strategic importance for the company's operations are: research and development, quality and marketing. The function of research and development is a fundamental driver of business development Continuous improvement of business processes is established by the implementation of quality management concept. Marketing enables the formation of market position and directs business activity of an enterprise in regard to the perceived needs and expressed demands of consumers. The function of marketing is integrative, because it relates not only these three, but all the other functions in the enterprise in order to achieve a stable market position of the company.

Business operations within the terms of the global economy are changing. Today, business organizations have become aware of the fact that they affect the society. This finding has farreaching consequences. Implementing the principles of corporate ethics also has a global character. Public interest is the primary interest of the organization, which must be integrated into the business policy of the organization while the business policy of the organization has to be fully implemented in the business. Modern organizations should be directed towards sustainability, which involves meeting the demands of consumers and aims of the enterprise, taking into consideration the future.

Successful business in the global market implies product differentiation, quality and effective marketing communication.

\section{ASPECTS OF IMPROVING THE CONTEMPORARY ORGANIZATION BUSINESS}

Contemporary economy is determined by the new competitive circumstances. On the global market new competitors have appeared, competing both with price and quality, lowering the price of the product.

Competitive relations are nowadays very complex. In the last twenty years competitive relationships have become more complex - the number of competitors on the global market has increased, the competition is being transferred from the level of product to the level of innovations, competition takes place between large and small as well as medium-sized enterprises, etc.

New competitors have appeared on the global market primarily from newly industrialized countries. These new competitive conditions identified by the increased role of companies from newly industrialized countries demand redefining marketing strategy which is aimed at the global market. New economic conditions require new approaches in the study of organizational management, as well as new approaches to business practice.

Kotler as well as Caslione considered (Kotler \& Caslione, 2009) that the global economy is characterized by the appearance of hyper competition. Hyper competition happens when technology and service offer are that much new that the standards and rules become fluid causing competitive advances that are impossible to stop. It is characterized by intense competition and rapid shifts in which competitors have to quickly build new strengths and surpass their rivals.

Competitiveness is the ability of companies to compete with other companies - competitors in the market (Bešić and Đorđević, 2014). Competitive advantage is the particular position of business organization when its service offer is seen by consumers as providing greater value compared to that of its competitors.

Porter believes that competitive advantage basically arises from the value that the company is able to create for its customers and which exceeds the cost of its creation. Value is what buyers are willing to pay, while exceptional value derives from the offer of lower prices than those of competitors for the equal benefit, or the unique benefits that largely neutralize higher price.

Porter believes that the five powers which define the shape of the strategy are:

1. Rivalry among existing competitors,

2. Threat of entry of new competitors into the market,

3. The growing importance and power of buyers,

4. Risk of substitution of products and services,

5. Bargaining power of suppliers, (Porter, 2008).

Integrated quality concept is one of the most important factors for achieving a stable market position in the modern business. The concept of quality management is primarily a commercial 
concept, which is based on the improvement of all business activities, ranging from market research, product development and production, logistics, market communication and evaluation of effects of business.

According to the Basic and Djordjevic (Bešić \& Đorđević, 2007), it is particularly important that the organizational structure is propulsive for information both at a hierarchical vertical, and at horizontal level. Contemporary organizations require productive project teams, where there is no leader - each team member must possess leadership qualities as well as entrepreneurial skills. Strong leadership personalities of the twentieth century have been replaced by powerful teams of individuals who are willing to through teamwork respond to all challenges of the future. Creativity, innovation and the advancement of knowledge are the fundamentals of successful project teams.

Traditional organization, founded on establishment of a solid command line, focused on activities, is impervious for information and faces only the production process, which is outdated. It changes into a new organization that is focused on processes, with direct access to customers, an organization that is propulsive regarding information, which is run by leadership teams, based on multitasking and outsourcing.

Economic behavior of companies includes such behavior based on the effective achievement of business goals. This primarily involves the exercise of enterprise, and maximizes the business results with a minimum of necessary investments (Bešić \& Đorđević, 2014).

In the information society, knowledge becomes the fundamental resource of economy. Knowledge is becoming the decisive factor of production. Companies will not be able to compete and be successful if they are not transformed into organizations based on teamwork and focusing on processes. Knowledge society must necessarily be the professional organization of society, and the main task of management is to make knowledge productive.

Drucker (Drucker, 2003) argues that the knowledge society should at its core contain the concept of an educated individual. It will have to be a universal model, because the knowledge society is - a society of diverse knowledge and global in its nature. In the knowledge society there is no queen of knowledge. All skills are equally valuable and they equally lead to the truth.

In order to achieve market success it is necessary for the company to possess a competitive advantage in the form of lower costs and product differentiation, with a long-term strategy of providing products and services of high quality with continuous innovation. Companies must invest more significant efforts to meet the requirements, better educated and more informed consumers and users. The task of the modern organization is to improve the knowledge of their employees.

Corporations are becoming more aware of their own intellectual capital - whether they are patents, process knowledge, technology, management skills, marketing and market information, information on competitors, the concepts of new products, research on customers and suppliers, competitive analytical patents, licenses, rights, ideas to improve processes and procedures, their management requires constant supervision. And not only should modern organization create knowledge, it must also increase the value.

\section{MODERN ORGANIZATION AND APPLICATION OF PRINCIPLES OF SOCIAL RESPONSIBILITY}

In order to achieve business excellence, we need to continuously improve our business. Improving the business assumes the character of continuous improvement of the quality of operations, (Ćoćkalo et al, 2015).

In that sense, the basic aspects of the quality of operations are: marketing aspect, business aspect and social aspect, (Heleta, 1995). Market aspect of improving the quality of operations is related to satisfaction of consumer needs, suitability of use, market positioning and the achievement of competitive advantage. Commercial aspect of improving the quality of operations refers to the improvement of the quality of internal economy organization - an increase in efficiency, reduction of costs, increase of labor productivity and knowledge, increase of profit. The social aspect of improving the quality of an organization implies improvement of the welfare of society by improving the quality of life:

- protection of human health, 
- safety and health protection of workers,

- protection and consumer safety,

- protection and improvement of the environment,

- conserving natural resources,

- safety of all in the society,

- Business coordinated according to regulations, (Bešić \& Đorđević, 2007).

The social aspect of quality management combines business and market quality aspect, enabling the realization of synergy in relation to the competitive position of the company. Successful management of the company, which is expected to result the achievement, maintenance and improvement of competitive position on the market, assumes the implementation of the principles of social responsibility in the organizational structure of an enterprise.

Contemporary business philosophy assumes that an enterprise has to be responsible for its actions and deeds towards all stakeholders in the environment - both in the macro environment, but also in the company. In that sense, the company is obliged to meet all the demands of consumers, companies, partners, employees and shareholders. This business philosophy is referred to as Total Quality Management - TQM (abbr. for English Total Quality Management). Total quality management is a business philosophy that is created as a logical and historical response of entrepreneurs to the requirements set by modern society. This is a continuous improvement of the entire business of the organization, which includes the integration of technological, market, economic, organizational and ethical business goals. This concept implies: meeting the needs of consumers, the development of business quality, safety of the employees, environmental protection, education of employees and the creation of a corporate culture of the organization. The ultimate goal of applying the concept of TQM is to improve the quality of life. Seen in this way, the entire system is based on the individual, who has to become a "responsible individual" who contributes to the increase of productivity by his actions, and therefore the general well-being.

Improvement of corporate social responsibility is closely related to the development of methods and techniques of marketing, especially marketing communications. Developed marketing communication influences the improvement of corporate image while social initiatives within the scope of corporate social responsibility directly affects the image of the company in public, divided by target segments.

According to Kotler et al. (Kotler et al., 2014), since the effects of marketing are felt outside the company, overcoming consumers, as well as to reflect on the society as a whole, marketing must take into account the ethical, legal and social context in relation to the environment and their total operation.

Application of the concept of corporate social responsibility in the domestic enterprises should facilitate the establishment of conditions for successful market performance and the achievement of competitiveness of domestic enterprises. The main driver of these activities has to be knowledge. It is particularly important to promote knowledge management in the field of modern management methods and techniques.

\section{APPLICATION OF METHODS AND TECHNIQUES OF PUBLIC RELATIONS IN THE DEVELOPMENT OF CORPORATE SOCIAL RESPONSIBILITY}

The largest number of domestic enterprises is insufficiently competitive on the global market. Similarly, this is the case with companies from countries in transition. The chronic lack of capital in the countries in transition, lack of new technologies, along with poor educational level of employees in enterprises dominated by domestic capital, result in a poor competitive ability. Companies that are struggling to survive due to a lack of capital on the finance markets in countries in transition neither have time, nor financial resources to seriously dedicate themselves to the application of modern management knowledge. Even those enterprises that partially adopted some modern methods and techniques of management, such as management system quality and integrated management systems, due to the lack of financial resources face problems with further development.

It is believed that the initiators of inappropriate quality business decisions are: unrecognized liability and unrecognized importance of the problem and the decision-making process, ignoring the nature of business decisions and insufficient awareness of the usefulness (Yates, 2009). 
On the other hand, managers of companies from countries in transition are aware of the need for application of modern management methods and techniques that are based on knowledge. Domestic leaders are particularly aware of the need for applying the system of management quality, as well as other management standards.

The result of the research engaged with the analysis of application of modern management methods and techniques in domestic enterprises, indicated that the most important methods and techniques of management that should be applied are as follows: governance databases $(18.4 \%)$, the quality management system $(17.6 \%)$, corporate social responsibility $(17.6 \%)$, relationship marketing (16.8\%) and benchmarking (12.6\%), (Bešić et al., 2013).

The main problems that arise in the process of organizational management in the countries in transition are as follows: failure to adopt the logic of modern management, lack of understanding of the integral approach to the process of organizational management, marketing misconception, inadequate treatment of investments in marketing, issues of organizational structure, insufficient speed of adoption of new trends, methods and techniques in management. Domestic enterprises are still at the stage of initial acceptance of modern principles and techniques of management, not all, but only those who have successfully completed the process of transformation, (Bešić \& Đorđević, 2007).
The research results which were used to analyze the possibilities of using modern methods and techniques of public relations in business organizations on the market of Bosnia and Herzegovina aimed at improving corporate social responsibility (completed in 2015 on the territory of Bosnia and Herzegovina, the pattern projected on the 50 units - executives of companies), precisely indicate this fact (Đervida-Lekanić 2015).

The analyzed leaders find that segment marketing communication within the marketing mix, especially public relations have a highly important impact on the general public, which includes not only customers, but also the entire environment with all stakeholders. The primary function of public relations is to maintain two-way communication with the environment, and this means not only disclosure and press releases, but also monitoring the reaction, that is public opinion polls and opinions primarily of the target population.

Joint coordination of all segments of the company is planned joint operations which complements each other and strive towards achieving the goal.

Based on a survey of attitudes of experts in the field of public relations (PR) one can distinguish the main obstacles in the implementation of public relations in local companies: shown in the figure 1.

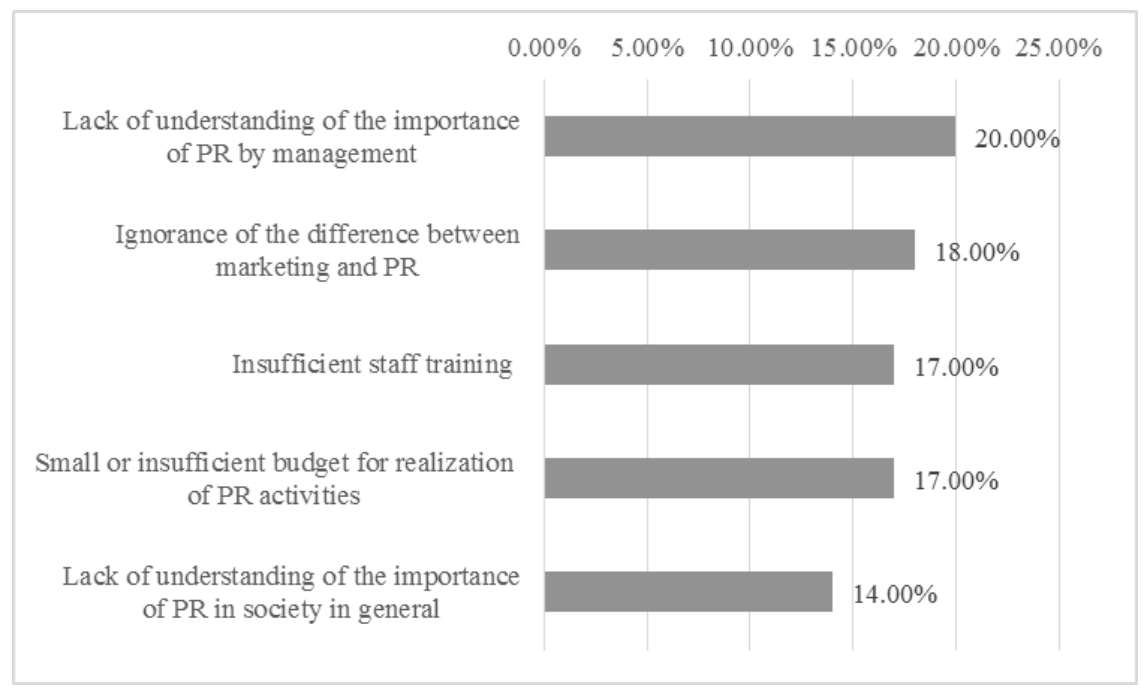

Figure 1: Main obstacles in the implementation of public relations in local companies: 
The basic elements for business improvement and development of competitive ability of the company we can stand out in the figure 2 .

As the most important incentive to companies to accept CSR we can stand out the following order:

1. Tax incentives in the business $-27 \%$,

2. Education - $24 \%$,

3. Legal regularity $-24 \%$,

4. Better business environment - $12 \%$,

5. Organizing economic situation $-9 \%$.

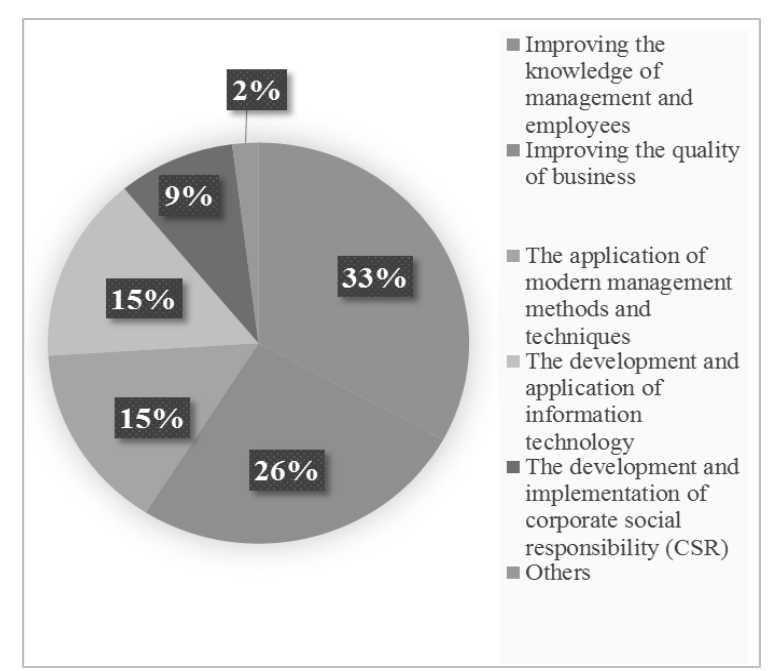

Figure 2: The basic elements for business improvement and development of competitive ability

Model for improving domestic marketing communications of companies on the market of Bosnia and Herzegovina based on the application of the concept of public relations, includes the following elements:

1. Meeting the requirements of the target public,

2. The main obstacles in the implementation of public relations in the domestic enterprises,

3. Elements for business improvement and development of competitive position,

4. The most important incentive for companies accepting CSR,

5. Increase Business Productivity,

6. PR in the function of satisfying target audiences and

7. Continuous business improvement.

As a starting point for defining business objectives, companies must take into account the requirements of users and other target audiences in the region. This means that the initial activities must be directed at achieving, maintaining and developing fulfillment of the requirements of the target public.
Without satisfying its customers it is impossible to fully realize the business goals, which means that the management has to represent not only the interests of the company but also the interests of the society in which it operates. Therefore, it is necessary to complete the market analysis to spot the target audience and their needs and based on this plan strategic activities in order to meet their demands and needs.

Domestic enterprises need to internationalize the business process based on the application of international experience, international standards and internationally accepted business practices. Application of modern methods and techniques of marketing communications, where public relations are certainly the most important, we need to create the conditions for enterprises to become more competitive in the market, taking into account the need for socially responsible business.

The best way for the proper functioning and management of the enterprise is a legal framework that is one of the preconditions for the implementation of CSR in the company's business strategy. Legislation and incentives in the business should be done by the example of countries that have passed this phase of development. For the promotion of responsible business an important role should be played by public relations for the benefit of the company and the community. Businesses gain greater community support and also a better competitive position in the market. The benefit of the community is a better environment for living and less socio-economic problems. The goal of public relations is the identification and harmonization of company goals with the goals of the communities in which they operate, which is achieved only through the process of communication.

\section{CONCLUSIONS}

Management of modern business organization in the global economy requires innovation, flexibility and knowledge. Outdated models of organization management are replaced with new, more sophisticated models, which are adapted to modern market conditions. The essence of the struggle for competitiveness lies in accepting changes. Knowledge is the key driver of continuous growth in business productivity.

Domestic enterprises have to ground the process of internationalization of business on the application 
of international experience, international standards and internationally accepted business practices. Quality starts with management.

Businesses are the major factor in the development of corporate social responsibility. Since the concept is by definition voluntary, the companies are to decide whether to engage in socially responsible activities and the choice of the means of implementation. The completed survey showed that public relations are equally important for both large and small and medium-sized enterprises and are not intended only to build the reputation and the reputation of large companies. Changes in awareness and business practices will affect the development of the profession. Consumers and communities will become increasingly important, and this will influence the communication and increasingly emphasized two-way exchange of information. The exchange of information between companies and the environment creates a greater connection between the company and the community, which directly influences the development of corporate social responsibility, and further competitive advantage.

In Bosnia and Herzegovina there is an enormous number of social problems, which implies much greater state involvement and that of the enterprises. The state should influence the creation of an environment that will be supportive environment for businesses to operate in a socially acceptable manner. At the same time raising awareness and knowledge of sustainable development is one of the important factors of social responsibility which should start with education of children in kindergartens, which represents education of the whole society.

\section{REFERENCES}

Bešić, C., \& Đorđević, D. (2007). Benchmarking (in Serbian). Čačak: Technical faculty.

Bešić, C., \& Đorđević, D. (2014). Knowledge management (in Serbian). Čačak: Faculty of technical science.

Bešić, C., Krnjević-Mišković, Z., \& Đorđević D., (2013). The role of knowledge in the development process of competitive ability of domestic companies on the global market. Paper preented on III International Conference LEMiMA, Belgrade.

Ćoćkalo, D., Đorđević, D., Bešić, C., \& Bogetić S. (2015). Undergraduate business students attitudes towards CSR and competitiveness of Serbian economy. Journal of engineering management and competitiveness (JEMC), 5(1), 12-20.

Đervida-Lekanić, R. (2015). Analysis of the impact of public relations on the development of corporate social responsibility (in Bosnian). Banja Luka: UPS.

Đorđević, D., Ćoćkalo, D., Bogetić, S., \& Bešić, C. (2012). Razvoj poslovne izvrsnosti $i$ konkuretnost domaćih preduzeća, Paper presented on International conference JUSK 2012. JUSK, Belgrade.

Drucker, P. (2003). Moj pogled na menadžment (in Serbian). Novi Sad: Adižes.

Heleta, M. (1995). With Quality to World (in Serbian). Belgrade: Magenta Z.I.

Kotler, P., \& Caslione, J. (2009). Chaotics (in Croatian). Zagreb: Mate.

Kotler, P., \& Keller, K.L., \& Martinović, M. (2014). Marketing management (in Croatian). Zagreb: Mate.

Porter, M. (2008). The five competitive forces that shape strategy. Harvadr Business Review, 79-93

Yates, F. J. (2009). Decision Management, How to Assure Better Decisions in Your Company (in Croatian). Zagreb: Mate. 


\section{ANALIZA ULOGE ODNOSA SA JAVNOŠĆU U POBOLJŠANJU DRUŠTVENE ODGOVORNOSTI PREDUZEĆA}

Osnovni cilj savremenog poslovanja je postizanje poslovne izvrsnosti i dostizanje svetske klase proizvoda i usluga. Preduzeća koja aktivno i kontinualno primenjuju savremene metode i tehnike menadžmenta, posebno marketinga, imaju znatno bolju šansu da ojačaju svoju konkurentsku sposobnost na globalnom tržišu i da zauzmu stabilnu tržišnu poziciju sa perspektivom za dalji tržišni rast. Savremena poslovna filozofija podrazumeva da organizacija mora da bude odgovorno za svoje akcije i postupke i to prema svim akterima u okruženju. Postizanje ciljeva poslovno izvrsnosti organizacije pretpostavlja izgrađenu korporativnu društvenu odgovornost. Rezultati istraživanja prikazani u ovom radu su korišćeni za analizu mogućnosti korišćenja savremenih metoda i tehnika odnosa s javnošću u poslovnim organizacijama i unapređenje društveno odgovornog poslovanja na tržištu Bosne i Hercegovine.

Ključne reči: Društvena odgovornost preduzeća, Odnosi s javnošću, Organizacija, Kvalitet, Bosna i Hercegovina. 